\title{
Pembuatan Rencana Strategis SI/TI Sebagai Acuan Pengembangan SI/TI Rumah Sakit Pelabuhan Palembang
}

\author{
Netti Herawati, Dedy Syamsuar \& Yesi Novaria Kunang \\ Universitas BinaDarma \\ Email: nettiherawati.9907@gmail.com
}

\begin{abstract}
The Palembang Port Hospital has used and utilized IT tools in line with the vision of becoming the best hospital in the national health industry with world-class professional services. To benefit from the use of IT equipment, the management of the Palembang Port Hospital must have knowledge of how the device is planned properly so that the results obtained are as expected. Otherwise it will cause a mismatch between the current device / application and the application needed in the future. Based on this, a strategic planning is required so that IT development runs directed and in accordance with the expected values of hospital management. The preparation of this strategic plan uses the Anita Cassidy framework in 4 phases, namely (1) Visioning Phase discusses current business conditions, (2) Analysis Phase discusses current IT conditions, (3) Direction Phase contains IT planning stages and (4) Recommendation Phase is the final result of the preparation of a strategic plan in the form of a final roadmap. In the preparation of the strategic plan for the Palembang Port Hospital, 9 projects were identified, namely 3 projects related to applications, 4 projects related to network infrastructure development, 2 documentation projects and IT training. In addition, an estimate of the time the project will start is also developed.
\end{abstract}

Keywords: strategic planning, hospital, Anita Cassidy, SWOT

\section{Pendahuluan}

Sistem Informasi dan Teknologi Informasi (SI/TI) secara fundamental memainkan peranan yang sangat penting bagi perkembangan organisasi di seluruh sektor, baik sektor kesehatan, industri, swasta dan pemerintah. Sampai pada suatu titik dimana bisnis tidak akan optimal tanpa adanya dukungan IT. Pada Peraturan Pemerintah Republik Indonesia Nomor 44 Tahun 2009, tentang Rumah Sakit yaitu pasal 52 Ayat 1 yang berbunyi "Setiap rumah sakit wajib melakukan pencatatan dan peloparan tentang semua kegiatan penyelenggaraan Rumah Sakit dalam bentuk Sistem Informasi Manajemen Rumah Sakit”. Tujuan dari perencanaan Strategis Teknologi Informasi adalah agar sebuah organisasi dapat mengenali target terbaik untuk melakukan pembelian dan penerapan teknologi informasi manajemen dan membantu untuk memaksimalkan hasil dari investasi pada bidang teknologi informasi. Sebuah teknologi informasi yang dibuat berdasarkan perencanaan strategis teknologi informasi yang baik, akan membantu sebuah organisasi dalam pengambilan keputusan untuk melakukan rencana bisnisnya dan merealisasikan pencapian bisnisnya (Cassidy, 2006).

Rumah Sakit Pelabuhan Palembang merupakan rumah sakit Tipe C yang beralamat di Jalan Mayor Memet Sastrawirya, Palembang. Rumah Sakit Pelabuhan memiliki 4 (empat) cabang yaitu Rumah Sakit Pelabuhan Jakarta (Pusat), Rumah Sakit Pelabuhan Palembang, Rumah Sakit Pelabuhan Cirebon, Rumah Sakit Pelabuhan Port Medical Centre. Proses bisnis dalam Rumah Sakit Pelabuhan Palembang menggunakan sistem informasi Aplikasi Developer 6 Database Oracle dari Developer Kantor Pusat Rumah Sakit Pelabuhan Jakarta. Dalam Sistem informasi Rumah Sakit Pelabuhan ini belum adanya Standar Operasional Prosedur (SOP), pedoman acuan infrastruktur renstra SI/TI sehingga target dan tahapan pengembangan IT

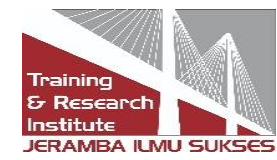


nya kurang jelas dan karyawan kesulitan ketika akan dilakukan pencapaian, padahal dengan adanya renstra SI/TI semua hal terkait sistem informasi yang dijalankan akan lebih terarah dan sistematis yang nanti nya dapat digunakan oleh pihak manajemen sebagai acuan dalam pengembangan rencana strategis SI/TI baik hal yang terkait internal maupun eksternal.

Berdasarkan pemaparan diatas, maka dalam tesis ini peneliti ingin melakukan penelitian

dengan judul "Pembuatan Rencana Strategis SI/TI sebagai acuan pengembangan SI/TI di Rumah Sakit Pelabuhan Palembang”. Kerangka Kerja (Famework) yang akan digunakan dalam penelitian ini adalah kerangka kerja dari Cassidy yang dikeluarkan pada tahun 2006. Berdasakan kerangka kerja Cassidy tersebut, terdapat 4 (Empat) tahap yakni, visioning, Analysis, Direction, Recomendation. Adapun alasan menggunakan framework Anita Cassidy dalam penelitian ini adalah framework Cassidy membahas proses perencanaan dengan menggabungkan antara keselarasan sisi bisnis dan sisi TI yang tergambar dalam setiap fase. Alasan lain pemilihan framework Cassidy adalah karena framework ini membahas keseluruhan aspek TI mulai dari sisi aplikasi, infrastruktur jaringan dan struktur organisasi TI.

\section{Tinjauan Literatur}

Proses Perencanaan SI/TI Rumah Sakit Menggunakan Anita Cassidy 2006 terdiri dari empat

Fase perencanaan strategis:

\section{Fase Visioning}

Ini adalah tahap pertama dalam perencanaan strategis sistem informasi. Tujuan dari fase ini untuk menentukan visi dari kegiatan ini serta menyusun rencana proyek berikut prosesprosesnya yang ada di dalam. Pada tahap ini harus dapat dipahami seluruh tujuan, proses dan cakupan setiap proses bisnis secara menyeluruh. Tools yang dapat membantu pada tahap ini yaitu SWOT.

\section{Fase Analysis}

Setelah mengetahui seluruh proses bisnis di organisasi tersebut, langkah selanjutnya yang harus dilakukan adalah melakukan analisis terhadap kondisi sistem informasi. Hal ini bertujuan untuk mengetahui bagaimana sistem informasi yang sudah berjalan pada organisasi tersebut, perananannya selama ini, dan sebagaiupaya untuk mengkomunikasikan tujuan organisasi dengan kondisi sistem informasi.

\section{Fase Direction}

Selanjutnya pada fase ini akan dibangun sebuah pernyataan tentang visi dan misi sistem informasi berdasarkan kondisi yang telah dipahami pada dua fase sebelumnya. Fase ini bertujuan untuk menetukan arahan sistem informasi kedepan yang diawali dengan merancang visi dan arahan dari sistem informasi baru, seluruh pihak yang terlibat harus dikomunikasikan agar seluruh pihak mempunyai visi dan arahan yang sama dalam membangun sistem informasi yang telah dikembangkan sehingga pada akhirnya tujuan bisnis dan tujuan sistem informasi dapat diseleraskan.

\section{Fase Recommendation}

Fase terakhir adalah fase recommendation sebagai tahapan untuk mendokumentasikan dan merangkum seluruh proses yang telah dilakukan sebelumnya. Fase ini akan dihasilkan sebuah roadmap secara detail tentang pelaksanaan pengembangan sistem informasi

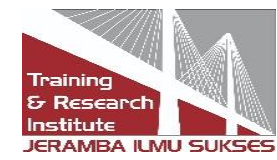


beberapa tahun ke depan yang mencakup ringkasan biaya, waktu pelaksanaan.

\subsection{Evaluasi Kepuasan Pengguna TI}

Skala Linkert adalah suatu skala psikometrik yang digunakan dalam kuisioner yang merupakan salah satu teknik yang digunakan dalam suatu evaluasi suatu program atau suatu kebijakan perencanaa (Saurik, 2015).

\subsection{Analisis SWOT}

Analisis SWOT adalah identifikasi berbagai faktor secara sistematis untuk merumuskan strategi perusahaan. Analisis ini didasarkan pada hubungan atau interaksi antara unsur internal, yaitu kekuatan dan kelemahan, terhadap unsure eksternal yaitu peluang dan ancaman (Antoni, Akbar \& Fatoni, 2018; Antoni, Fikari, Akbar \& Jie, 2018; Akbar \& Antoni, 2019; Ariana, Azim \& Antoni, 2020; Antoni, Jie \& Abareshi, 2020).

\section{Metode Penelitian}

\subsection{Pengumpulan Data}

Pada tahap awal ini akan dilakukan pengumpulan data yang dibutuhkan dalam penelitian ini menggunakan beberapa cara (Fauzi, Dencik \& Asiati, 2019) yaitu:

\section{Observasi}

Observasi adalah teknik pengumpulan data melalui pengamatana secara langsung pada objek penelitian, yaitu di Rumah Sakit Pelabuhan Palembang. Teknik ini merupakan teknik pengumpulan data yang efektif untuk mempelajari suatu sistem. Dengan teknik ini maka data yang didapat mempunyai nilai yang tinggi, karena penulis secara langsung melihat apa yang sedang dikerjakan.

\section{Wawancaa}

Dalam penelitian ini peneliti menggunakan metode wawancara digunakan untuk memperoleh keterangan tentang kejadian yang oleh peneliti tidak dapat diamati sendiri secara langsung. Adapun narasumber dalam wawancara ini langsung dengan Manager Teknologi Sistem Informasi di Rumah Sakit Pelabuhan Palembang.

\section{Studi Dokumentasi}

Studi dokumentasi dilakukan untuk mendapatkan data yang tidak diperoleh melalui teknik lainnya. Subyek yang menjadi sumber informasi dipilih melalui teknik lainnya. Subyek yang menjadi sumber informasi dipilih sesuai dengan fokus dan tujuan penelitian. Untuk meliputi sumber data dibutuhkan adanya informasi yang dipilih guna mendapatkan informasi sebanyak mungkin sesuai dengan kemampuannya, sehingga diperoleh keadaan studi dalam konteks tertentu.

\subsection{Sistem Informasi Rumah Sakit}

Sistem informasi rumah sakit (SIRS) adalah suatu tatanan yang berurusan dengan pengumpulan data, pengelolaan data, penyajian informasi, analisis dan penyimpulan informasi serta penyampaian informasi yang dibutuhkan untuk kegiatan rumah sakit. Sistem informasi rumah sakit ini meliputi : sistem informasi klinik, sistem informasi administrasi dan sistem informasi manajemen. Peran SIRS yang utama adalah dalam mendukung pengendalian mutu pelayanan medis, penilaian produktivitas, analisis pemanfaatan dan

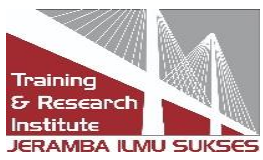


perkiraan kebutuhan, perencanaan dan evaluasi program, menyederhanakan pelayanan, penilaian klinis dan serta pendidikan (Sabarguna, 2008)

\section{Hasil dan Pembahasan}

Pada hasil pembahasan mengenai rencana strategis Rumah Sakit Pelabuhan Palembang terdiri dari dua fase yaitu fase direction dan recomendation. Pada fase terakhir dari framework Anita Cassidy yaitu fase recomendation diberikan roadmap dari rencana strategis teknologi informasi Rumah Sakit Pelabuhan Palembang.

\subsection{Analisa Situasi Teknologi Informasi Saat Ini}

Tabel 1 Sebaran jawaban kuisioner mengenai layanan bantuan terkait IT (Help Desk)

\begin{tabular}{llcccccccccccc}
\hline \multicolumn{10}{c}{ Layanan Bantuan IT (Help Desk) } \\
\hline \multicolumn{10}{c}{ Nomor Urut Pertanyaan } \\
\hline \multicolumn{1}{c}{} & $\mathbf{1}$ & $\mathbf{2}$ & $\mathbf{3}$ & $\mathbf{4}$ & $\mathbf{5}$ & $\mathbf{6}$ & $\mathbf{7}$ & $\mathbf{8}$ & $\mathbf{9}$ & $\mathbf{1 0}$ & $\mathbf{1 1}$ & Total \\
\hline 1 & MCU & 5 & 4 & 4 & 4 & 5 & 4 & 4 & 4 & 4 & 4 & 4 & 46 \\
\hline 2 & RADIOLOGI & 5 & 4 & 4 & 4 & 5 & 4 & 4 & 4 & 4 & 4 & 4 & 46 \\
\hline 3 & GIZI & 5 & 4 & 4 & 3 & 5 & 5 & 4 & 4 & 4 & 4 & 4 & 46 \\
\hline 4 & REHAB & 4 & 4 & 4 & 4 & 5 & 4 & 5 & 5 & 4 & 4 & 4 & 47 \\
\hline 5 & FARMASI & 5 & 4 & 4 & 4 & 5 & 4 & 5 & 5 & 5 & 5 & 4 & 50 \\
\hline 6 & MUTU & 4 & 4 & 4 & 4 & 5 & 4 & 4 & 4 & 5 & 5 & 5 & 48 \\
\hline 7 & LAB & 5 & 5 & 4 & 4 & 5 & 4 & 4 & 4 & 4 & 5 & 4 & 48 \\
\hline 8 & MARKETING / P2P & 5 & 4 & 4 & 4 & 4 & 4 & 4 & 5 & 4 & 4 & 4 & 46 \\
\hline 9 & MEDICAL RECORD & 4 & 5 & 4 & 5 & 4 & 5 & 5 & 5 & 5 & 5 & 4 & 51 \\
\hline 10 & HRD & 5 & 5 & 5 & 3 & 5 & 4 & 4 & 4 & 4 & 4 & 4 & 47 \\
\hline 11 & POLI & 4 & 4 & 4 & 4 & 5 & 4 & 4 & 4 & 4 & 4 & 4 & 45 \\
\hline 12 & Keuangan & 4 & 5 & 4 & 4 & 5 & 5 & 4 & 4 & 4 & 5 & 3 & 47 \\
\hline \multicolumn{1}{r}{} & Total & & & & & & & & & 567
\end{tabular}

Berdasarkan data diatas untuk mengetahui sikap keseluruhan responden mengenai

Layanan Bantuan IT (help Desk) yakni:

Berdasarkan keseluruhan responden:

Menentukan skor maksimal : 5 x $11 \times 12=660$

$\square$ Menentukan skor minimal : 3 x 11 x $12=396$

Menentukan nilai median : $(660+396): 2=528$

Menentukan nilai kuartil $1:(528+396): 2=462$

$\square$ Menentukan nilai kuartil $3:(528+660): 2=594$

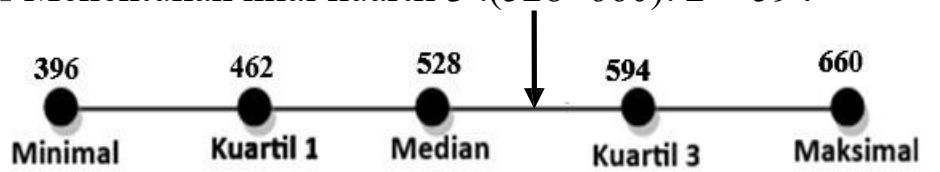

Penyelesaian : Rumus Index $=$ Total Skor $/$ Skor Maksimal x 100\%

$$
\begin{aligned}
& =567 / 660 \times 100 \% \\
& =85,90(\text { Sangat Baik) }
\end{aligned}
$$


Tabel 2. Sebaran jawaban kuisioner mengenai Perlengkapan dan Peralatan

Perlengkapan dan Peralatan

Nomor Urut Pertanyaan

\section{Total}

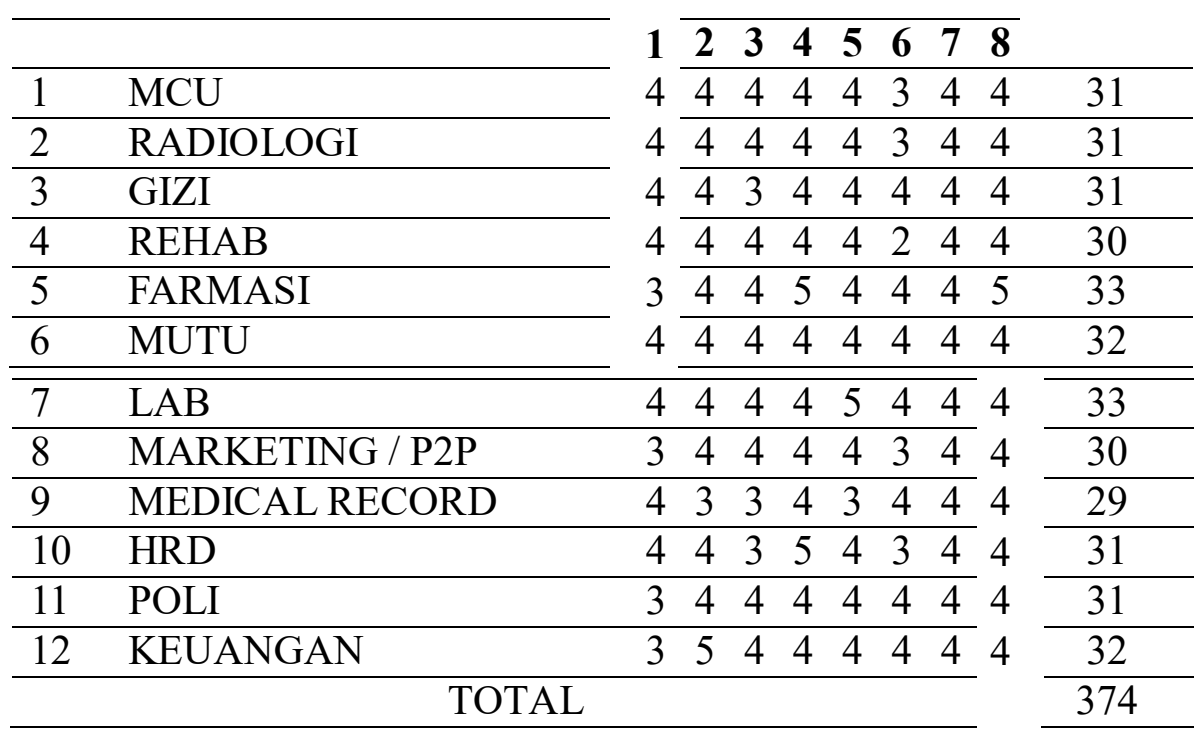


Berdasarkan data diatas untuk mengetahui keseluruhan responden mengenai

Perlengkapan dan Peralatan yakni:

Berdasarkan keseluruhan responden:

$\square$ Menentukan skor maksimal : 5 × 8 x 12=480

Menentukan skor minimal : 3 × 8 × $12=288$

Menentukan nilai median : $(480+288): 2=384$

$\square$ Menentukan nilai kuartil $1:(288+384): 2=336$

$\neg$ Menentukan nilai kuartil $3:(480+384): 2=432$

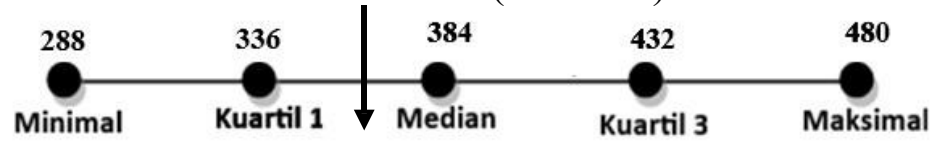

Penyelesaian : Rumus Index $=$ Total Skor $/$ Skor Maksimal x 100\%

$$
\begin{aligned}
& =374 / 480 \times 100 \% \\
& =77,91 \text { (Baik) }
\end{aligned}
$$

Tabel 3. Sebaran jawaban kuisioner mengenai Training atau Pelatihan

Training dan Pelatihan

Nomor Urut Pertanyaan

\begin{tabular}{|c|c|c|c|c|c|c|c|}
\hline & & 1 & 2 & 3 & 4 & 5 & \\
\hline 1 & $\mathrm{MCU}$ & 4 & 3 & 3 & 1 & 1 & 12 \\
\hline 2 & RADIOLOGI & 4 & 3 & 3 & 3 & 3 & 16 \\
\hline 3 & GIZI & 4 & 2 & 3 & 1 & 2 & 12 \\
\hline 4 & REHAB & 4 & 4 & 3 & 3 & 3 & 17 \\
\hline 5 & FARMASI & 4 & 3 & 3 & 1 & 2 & 13 \\
\hline 6 & MUTU & 4 & 4 & 4 & 3 & 3 & 18 \\
\hline 7 & LAB & 4 & 3 & 4 & 1 & 2 & 14 \\
\hline 8 & MARKETING / P2P & 4 & 3 & 4 & 1 & 3 & 15 \\
\hline 9 & MEDICAL RECORD & 4 & 4 & 4 & 4 & 3 & 19 \\
\hline 10 & HRD & 4 & 3 & 4 & 3 & 3 & 17 \\
\hline 11 & POLI & 4 & 3 & 3 & 2 & 2 & 14 \\
\hline \multirow[t]{2}{*}{12} & KEUANGAN & 4 & 2 & 3 & 1 & 2 & 12 \\
\hline & TOTAL & & & & & & 179 \\
\hline
\end{tabular}

TOTAL

Berdasarkan data diatas untuk mengetahui sikap tiap responden mengenai Training

Dan Pelatihan yakni:

Berdasarkan tiap responden:

- Menentukan skor maksimal : 5 x 5 x 12= 300

- Menentukan skor minimal : 1 × 5 × $12=60$

- Menentukan nilai median : $(240+60): 2=150$ 
- Menentukan nilai kuartil $1:(180+60): 2=120$

Menentukan nilai kuartil $3:(180+240): 2=210$

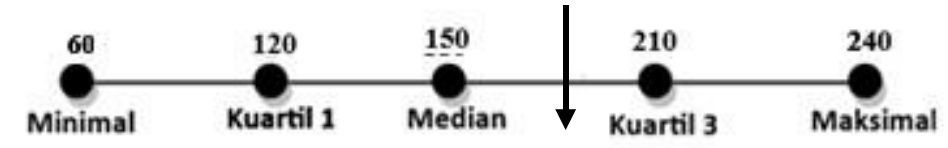


Penyelesaian : Rumus Index $=$ Total Skor $/$ Skor Maksimal x 100\%

$$
\begin{aligned}
& =179 / 300 \times 100 \% \\
& =59,66(\text { Cukup })
\end{aligned}
$$

Tabel 4. Sebaran jawaban kuisioner mengenai Proyek Aplikasi

Proyek Aplikasi

TOTAL

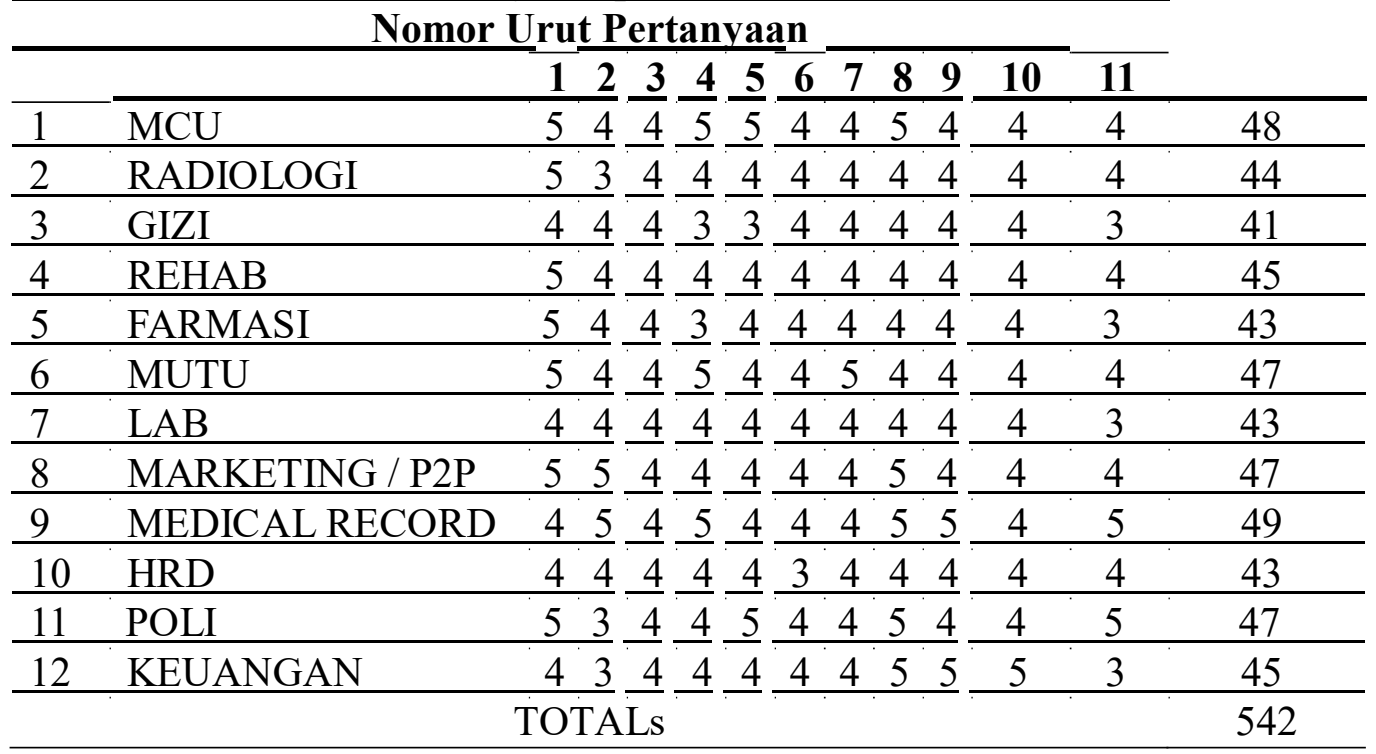

Berdasarkan data diatas untuk mengetahui sikap tiap responden mengenai Proyek Aplikasi yakni:

Berdasarkan tiap responden:

- Menentukan skor maksimal : 5 x 11 x 12=660

- Menentukan skor minimal : 3 x 11 x $12=396$

- Menentukan nilai median : $(660+396): 2=528$

- Menentukan nilai kuartil $1:(528+396): 2=462$

- Menentukan nilai kuartil 3 :(528+660): $2=594$

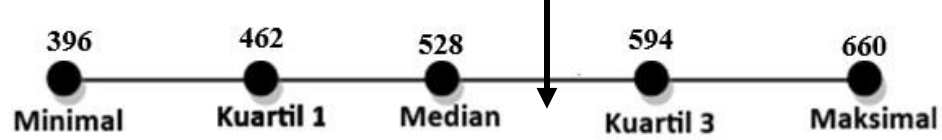

Penyelesaian : Rumus Index $=$ Total Skor $/$ Skor Maksimal x 100\%

$$
\begin{aligned}
& =542 / 660 \times 100 \% \\
& =82,12 \text { (Baik) }
\end{aligned}
$$


Tabel 5. Sebaran jawaban kuisioner mengenai TI Secara Keseluruan

TI Secara Keseluruhan

Nomor Urut Pertanyaan

TOTAL

\begin{tabular}{ll}
\hline 1 & MCU \\
\hline 2 & RADIOLOGI \\
\hline 3 & GIZI \\
\hline 4 & REHAB \\
\hline 5 & FARMASI \\
\hline
\end{tabular}

$\begin{array}{lllllllllll}1 & 2 & 3 & 4 & 5 & 6 & 7 & 8 & 9 & 10 & 11\end{array}$

$\begin{array}{llllllllllll}5 & 4 & 2 & 4 & 4 & 5 & 4 & 4 & 4 & 4 & 4 & 44\end{array}$

$\begin{array}{llllllllllll}5 & 4 & 2 & 4 & 3 & 4 & 4 & 4 & 4 & 4 & 4 & 42\end{array}$

$\begin{array}{lllllllllllll}5 & 4 & 2 & 4 & 4 & 4 & 4 & 4 & 4 & 5 & 4 & 44\end{array}$

$\begin{array}{lllllllllll}5 & 4 & 2 & 4 & 4 & 4 & 4 & 4 & 5 & 5 & 4\end{array}$

$\begin{array}{llllllllllll}5 & 4 & 2 & 4 & 4 & 4 & 4 & 4 & 4 & 4 & 4 & 43\end{array}$ 
Rincian persentase pada pertanyaan mengenai TI Secara Keseluruhan:

Berdasarkan tiap responden:

- Menentukan skor maksimal : 5 x 11 x 12=660

- Menentukan skor minimal : 2 x 11 x $12=264$

- Menentukan nilai median : $(660+264): 2=462$

- Menentukan nilai kuartil $1:(462+396): 2=429$

- Menentukan nilai kuartil 3 :(462+660): $2=561$

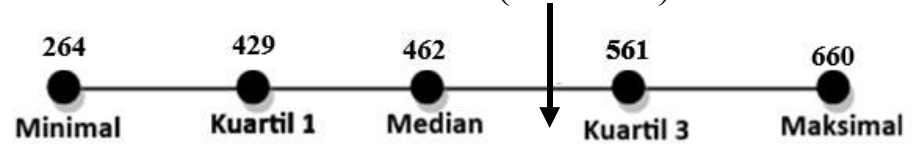

Penyelesaian : Rumus Index $=$ Total Skor $/$ Skor Maksimal x 100\%

$$
\begin{aligned}
& =530 / 660 \times 100 \% \\
& =80,30(\text { Baik) }
\end{aligned}
$$

\subsection{Analisa SWOT TI}

Tabel 6. Analisa SWOT TI RS.Pelabuhan Palembang

ANALISIS SWOT

Kekuatan dari Situasi T
KETERANGAN

1. Rumah Sakit Pelabuhan Palembang mempunyai sarana promosi kepada masyarakat berupa website.

2. Manajemen rumah sakit memiliki visi yang jelas untuk mendukung kemajuan di bidang TI rumah sakit.

3. Manajamen TI yang terdapat di Rumah Sakit Pelabuhan Palembang memberikan respon dan solusi yang cepat atas permintaan proyek aplikasi yang dibutuhkan. Hal ini diperkuat dengan skor 85,90 yang dikategorikan sangat baik atas jawaban responden.

4. Proses Operasional terintegrasi dengan sistem informasi. Hal ini diperkuat dari hasil wawancara atas petanyaan nomor 3 .

Kelemahan dari Situasi 1. Masih kurangnya pelatihan yang diterima karyawan TI yang menangani masalah TI dan dalam pengoperasian perangkat TI. Hal ini diperkuat dengan skor 59,66 yang dikategorikan cukup atas jawaban responden serta diperkuat dengan hasil wawancara atas petanyaan nomor 17 dan 18.

2. Tidak adanya arahan perencanaan pengembangan sehingga pengembangan TI terkesan tidak terarah. Hal ini diperkuat dari hasil wawancara atas petanyaan nomor 9 .

3. Jumlah sumber daya manusia di bidang teknologi 
informasi masih kurang. Diperlukan beberapa sumber daya manusia untuk menangani keseluruhan teknologi informasi terutama pada bagian jaringan yang ada di Rumah Sakit Pelabuhan Palembang. Hal ini diperkuat dari hasil wawancara atas petanyaan nomor 18 .

4. Belum terkoneksinya SIMOP Rumah Sakit dengan BPJS Kesehatan maupun Ketenagakerjaan.

\begin{tabular}{ll}
\hline Peluang dari Situasi TI & Meningkatnya akreditasi rumah sakit menjadikan TI \\
& memiliki peluang untuk memberikan dukungan penuh \\
& terhadap kemajuan rumah sakit dibidang teknologi.
\end{tabular}

2. Teknologi informasi secara keseluruhan merupakan salah satu peluang yang penting untuk meningkatkan kepercayaan masyarakat dalam mencapai visi rumah sakit.

Ancaman dari Situasi TI 1.Persaingan rumah sakit yang semakin banyak menjadikan Rumah Sakit Pelabuhan Palembang harus terus meningkatkan mutu pelayanan pasien terutama dari setiap poli terhubung ke sistem informasi farmasi tanpa harus psien menyerahkan resep ke bagian farmasi.

\subsection{Pengembangan visi dan misi teknologi informasi}

Arahan visi dan misi bagian TSI untuk 5 tahun kedepan yakni:

Visi

Menjadi rumah sakit terpercaya dalam pencapaian visi dan misi melalui penggunaan aplikasi teknologi informasi yang mudah diakses, terintegrasi untuk kebutuhan bisnis, serta memberikan dukungan terhadap ketersediaan data dan informasi.

Misi

Mendukung visi dan misi rumah sakit dengan memberikan pelayanan teknologi informasi yang baik dan terarah. 


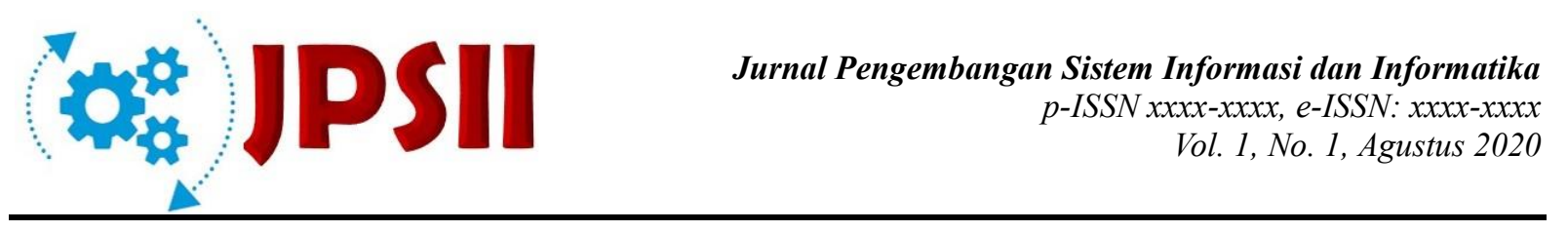

\subsection{Pengembangan arahan organisasional}

Berdasarkan ketentuan dari framework anita cassidy perlu diberikan definisi yang jelas mengenai bagian TI tersebut dengan menyusun kembali struktur oganisasi rumah sakit khususnya mengenai struktur bagian TI.

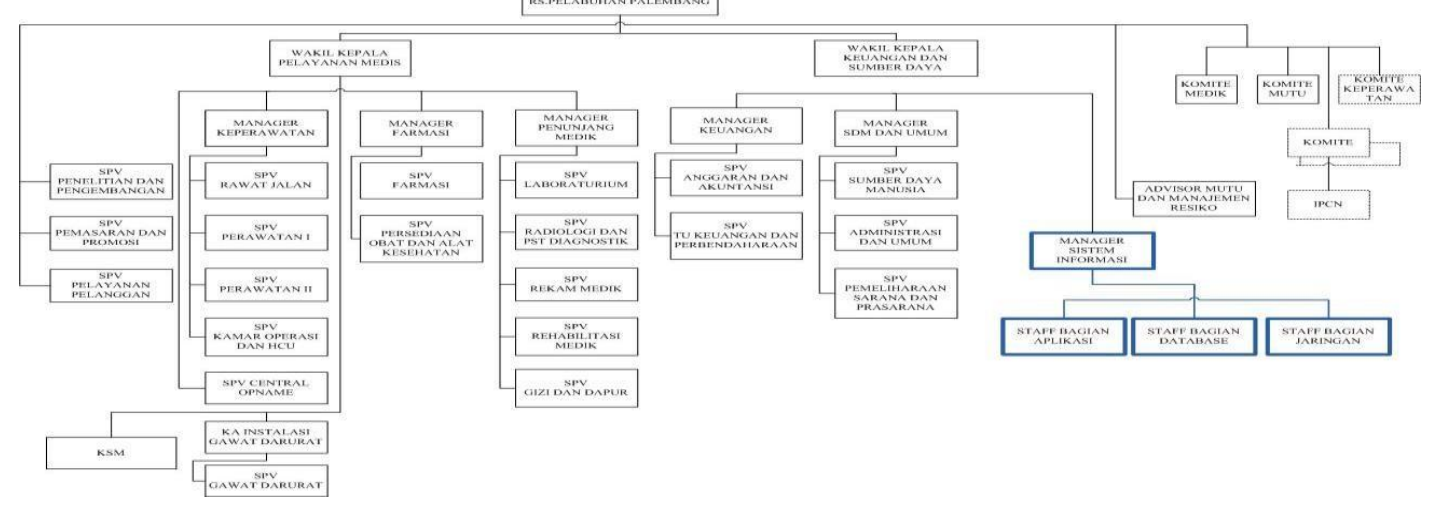

Gambar 3.1 Rekomendasi struktur organisasi 
4.5 Rekomendasi aplikasi pada penyusunan rencana strategis teknologi informasi rumah sakit Pelabuhan Palembang

Dilihat dari kondisi aplikasi yang ada saat ini serta kondisi bisnis yang diharapkan untuk masa depan, maka diperlukan pengembangan perangkat lunak (aplikasi) teknologi informasi di

Rumah Sakit Pelabuhan Palembang

Tabel 7. Rekomendasi aplikasi pada penyusunan rencana strategis teknologi

Informasi Rumah Sakit Pelabuhan Palembang

\begin{tabular}{|c|c|c|c|c|}
\hline No & Aplikasi & $\begin{array}{c}\text { Kondisi Yang } \\
\text { Ada }\end{array}$ & Gap Analysis & Kondisi Masa Depan \\
\hline 1 & $\begin{array}{l}\text { Layanan } \\
\text { Dokter Poli }\end{array}$ & 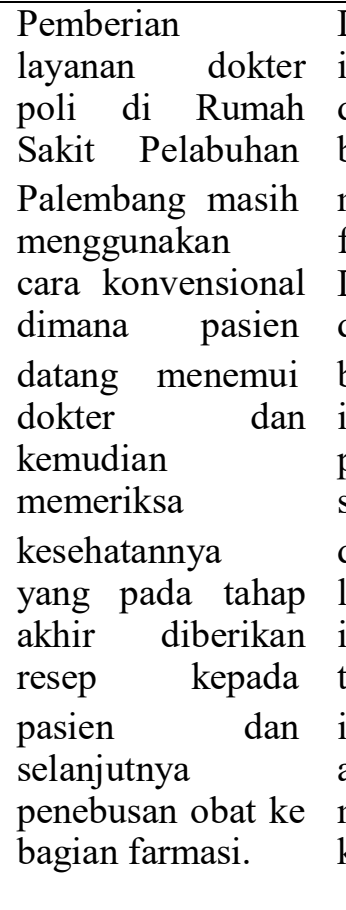 & 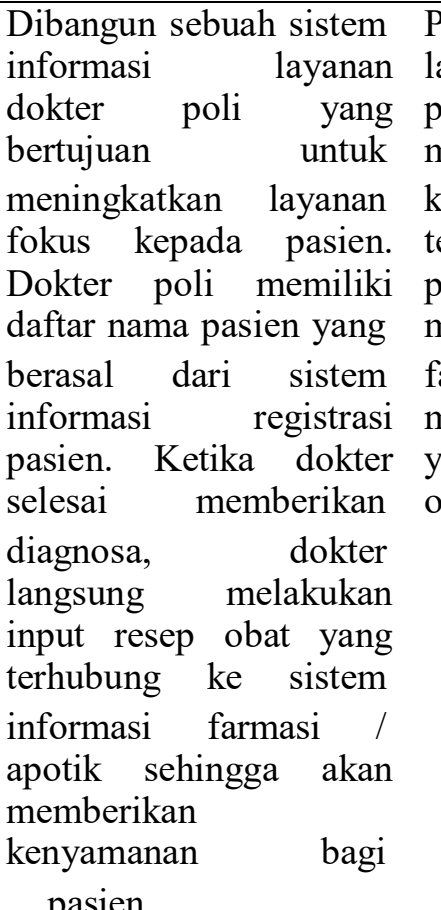 & \begin{tabular}{lrr} 
Pasien & \multicolumn{2}{c}{ mendapatkan } \\
layanan dari & dokter \\
poli & & dengan \\
memeriksakan & diri \\
kepada dokter & poli \\
tersebut. Tahap & akhir, \\
pasien hanya perlu \\
menunggu di bagian \\
farmasi & untuk \\
mendapatkan & obat \\
yang telah ditentukan \\
oleh dokter.
\end{tabular} \\
\hline 2 & Situs Web & $\begin{array}{l}\text { Situs web rumah } \\
\text { sakit hanya berisi } \\
\text { informasi umum } \\
\text { mengenai rumah } \\
\text { sakit pelabuhan. }\end{array}$ & $\begin{array}{l}\text { h Dilakukan } \\
\text { si pengembangan terhadap } \\
\text { h situs web rumah sakit } \\
\text { h pelabuhan palembang } \\
\text { sehingga memiliki nilai } \\
\text { lebih bagi rumah sakit } \\
\text { dan masyarakat umum. }\end{array}$ & $\begin{array}{l}\text { Situs web rumah sakit } \\
\text { sudah lebih variatif } \\
\text { t dan berguna untuk } \\
\text { i masyarakat umum } \\
\text { i }\end{array}$ \\
\hline 3 & $\begin{array}{l}\text { Sistem } \\
\text { Electronic } \\
\text { Medical } \\
\text { record } \\
(\text { EMR) }\end{array}$ & $\begin{array}{lr}\text { Tidak } & \text { adanya } \\
\text { Rekam } & \text { Medik } \\
\text { Elektrinik } & \text { (RME) }\end{array}$ & $\begin{array}{l}\text { Dibangun aplikasi untuk } \\
\text { mengeluarkan Rekam } \\
\text { Medik pasien baik } \\
\text { secara rekap maupun } \\
\text { detail. }\end{array}$ & $\begin{array}{l}\text { Adrministrasi rekam } \\
\text { medis elektronik } \\
\text { sebagai penyimpaan } \\
\text { informasi recara } \\
\text { elektronik mengenai } \\
\text { status kesehatan dan } \\
\text { layanan kesehatan } \\
\text { yang diperoleh pasien } \\
\text { sepanjang hidupnya. }\end{array}$ \\
\hline
\end{tabular}


4.6 Rekomendasi Infrastruktur Jaringan Pada Penyusunan Rencana Strategis Teknologi Informasi Rumah Sakit Pelabuhan Palembang

Berdasarkan kondisi infrastruktur jaringan yang ada saat ini dapat dilihat gap analysis bidang infrastruktur jaringan yang akan memberikan perbedaan anatara kondisi saat ini dan kondisi yang ingin dicapai pada masa depan. Gap analysis infrastruktur jaringan Rumah Sakit Pelabuhan

Palembang adalah seperti yang terlihat pada tabel dibawah ini:

Tabel 8. Rekomendasi Infrastruktur Jaringan Pada Penyusunan Rencana Strategis Teknologi Informasi Rumah Sakit Pelabuhan Palembang

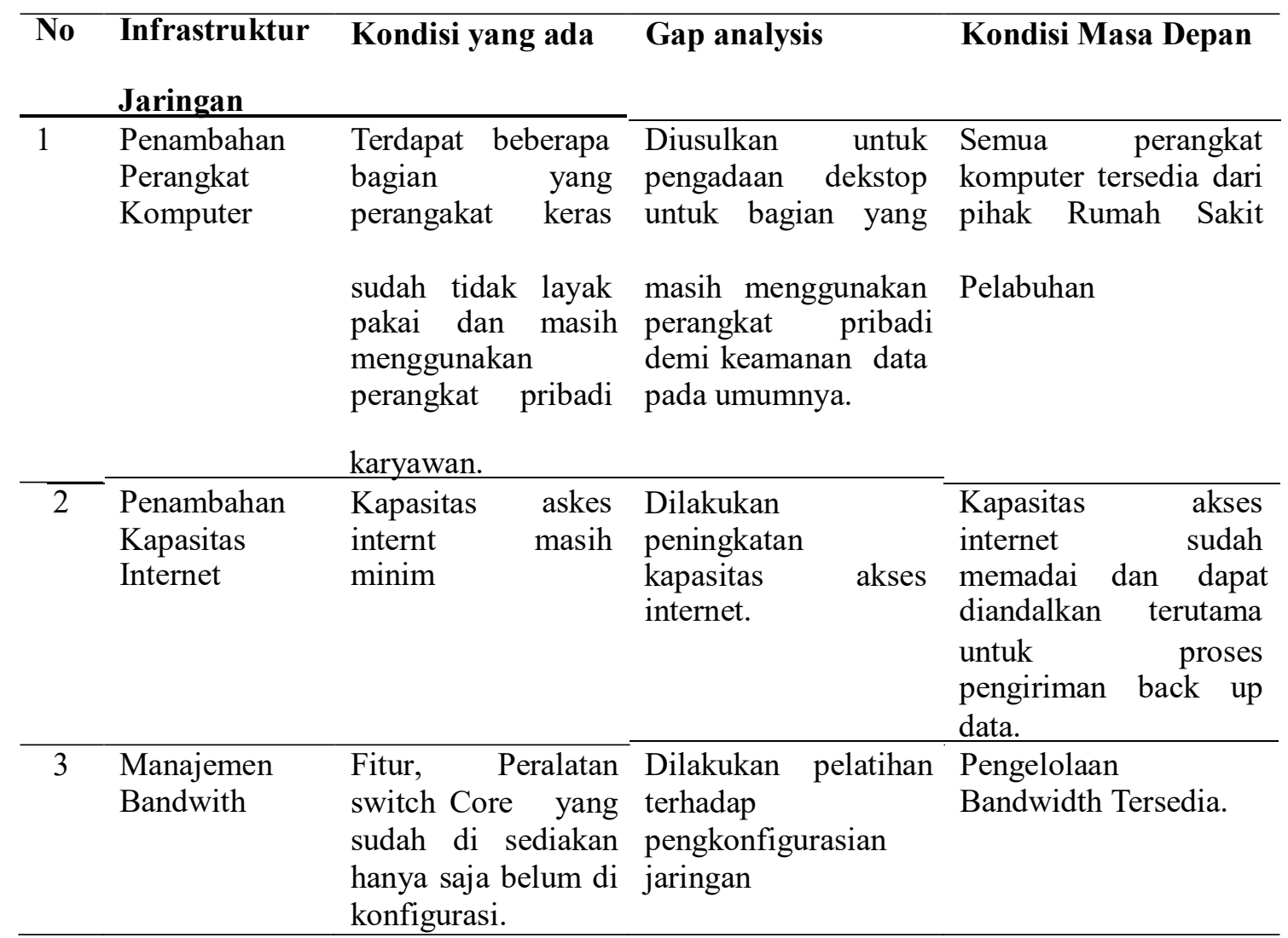

\subsection{Rekomendasi dokumentasi dan pelatihan pada penyusunan rencana strategis} teknologi informasi rumah sakit Pelabuhan Palembang

Pada rekomendasi sebelumnya dikembangkan perencanaan proyek di bidang jaringan untuk mendukung infrastruktur karyawan Rumah sakit Pelabuhan Palembang. Dalam rangka mengoptimalkan seluruh layanan di bagian TI, hal lain yang perlu diperhatikan adalah mengenai perencanaan dibidang pelatihan dan dokumentasi rumah sakit.

Tabel 9. Rekomendasi dokumentasi dan pelatihan pada penyusunan rencana strategis teknologi informasi rumah sakit Pelabuhan Palembang
No
Kategori
Kondisi
Gap analysis
Kondisi Masa Depan 


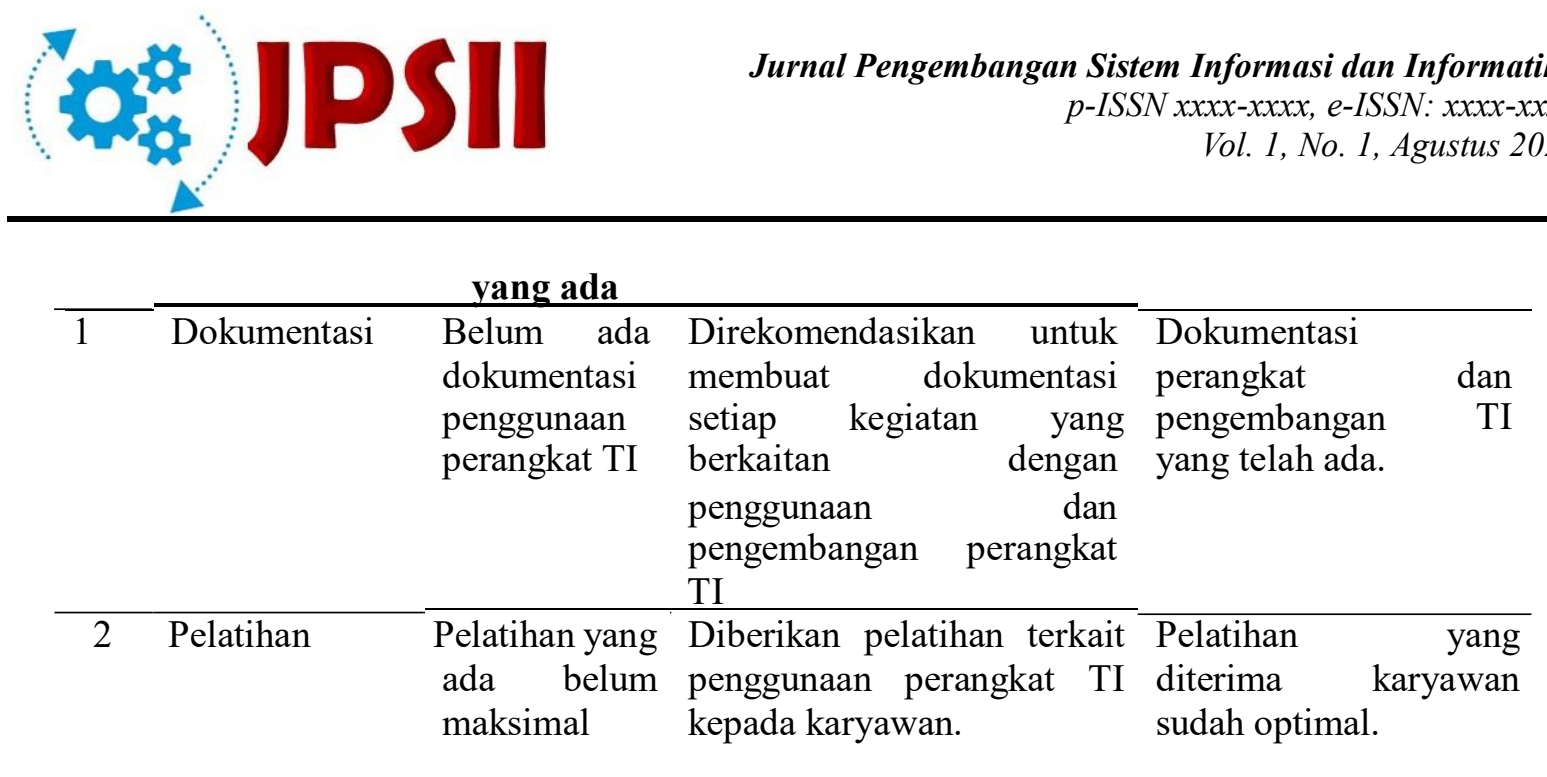




\section{Kesimpulan}

Dari hasil pengumpulan data dan analisis data pada bab sebelumnya, maka dapat diambil kesimpulan sebagai berikut:

1. Penyusunan rencana strategis TI di Rumah Sakit Pelabuhan Palembang menghasilkan 8

Proyek yang dikembangkan selama 5 tahun perencanaan dengan ruang lingkup :

(a) Recomendasi aplikasi sebanyak 3 Proyek yakni, Pembuatan aplikasi layanan dokter poli, pengembangan situs web, pembuatan aplikasi electronic medical record; (b) Recomendasi infrastruktur jaringan sebanyak 3 proyek yakni, penambahan perangkat

komputer, penambahan kapasitas akses internet, manajemen badwidth; (c) Recomendasi dokumentasi dan pelatihan.

2. Penyusunan rencana strategis dengan menggunakan framework dari anita cassidy membahas keseluruhan aspek TI yang dibutuhkan oleh Rumah Sakit Pelabuhan Palembang untuk

memcapai visi kedepan yaitu menjadi rumah sakit terbaik dalam industri kesehatan nasional dengan layanan profesional kelas dunia. Namun langkah perhitungan estimasi anggaran biaya tidak dijelaskan dalam penyusunan ini.

\section{Referensi}

Akbar, M., \& Antoni, D. (2019). E-supply chain management value concept for the palm oil industry. Jurnal Sistem Informasi, 15(2), 15-29.

Antoni, D., Akbar, M., \& Fatoni, F. (2018). Electronic government Rukun Tetangga model. Jurnal Sistem Informasi, 14(2), 64-73.

Antoni, D., Fikari, D., Akbar, M., \& Jie, F. (2018). The readiness of palm oil industry in enterprise resource planning. Telkomnika, 16(6).

Antoni, D., Jie, F., \& Abareshi, A. (2020). Critical factors in information technology capability for enhancing firm's environmental performance: Case of Indonesian ICT sector. International Journal of Agile Systems and Management, 13(2), 15-181.

Ariana, S., Azim, C., \& Antoni, D. (2020). Clustering of ICT human resources capacity in the implementation of E-government in expansion area: A case study from Pali regency. Cogent Business \& Management, 7(1), 1754103.

Cassidy, A. (2006). A practical guide to information systems strategic planning.

Fauzi, F., Dencik, A. B., \& Asiati, D. I. (2019). Metodologi Penelitian Untuk Manajemen dan Akuntansi. Jakarta: Salemba Empat.

Rangkuti, F. (2010). Analisis SWOT teknik membedah Kasus

Bisnis. Sabarguna, B. S. (2008). Sistem informasi rumah sakit.

Saurik, H. T. T., Yuniarno, E. M., \& Susiki, S. M. (2015). Kepuasan pemain terhadap desain rintangan pada skenario game petualang. In Seminar Nasional Informatika (SEMNASIF) 1(1).

\section{Copyrights}


Copyright for this article is retained by the author(s), with first publication rights granted to the journal.

This is an open-access article distributed under the terms and conditions of the Creative Commons Attribution license (http://creativecommons.org/licenses/by/4.0/) 